\title{
Effects of enamel matrix proteins on adherence, proliferation and migration of epithelial cells: A real-time in vitro study
}

\author{
MARZENA WYGANOWSKA-SWIATKOWSKA ${ }^{1}$, PAULINA URBANIAK ${ }^{2}$, DANIEL LIPINSKI ${ }^{3}$, \\ MARLENA SZALATA ${ }^{3}$, KAROLINA BORYSIAK ${ }^{2}$, JERZY JAKUN ${ }^{4}$ and MALGORZATA KOTWICKA ${ }^{2}$ \\ ${ }^{1}$ Department of Conservative Dentistry and Periodontology, Collegium Stomatologicum, Poznań University of Medical \\ Sciences, 60-812 Poznań; ${ }^{2}$ Department of Cell Biology, Poznań University of Medical Sciences, 60-806 Poznań; \\ ${ }^{3}$ Department of Biochemistry and Biotechnology, Poznań University of Life Sciences, 60-632 Poznań, Poland; \\ ${ }^{4}$ Urology Research Center, Department of Urology, College of Medicine and Life Sciences, \\ University of Toledo, Toledo, $\mathrm{OH} 43614$, USA
}

Received April 20, 2016; Accepted July 21, 2016

DOI: $10.3892 /$ etm.2016.3918

\begin{abstract}
Enamel matrix derivative (EMD) can mimic odontogenic effects by inducing the proliferation and differentiation of connective tissue progenitor cells, stimulating bone growth and arresting epithelial cells migration. To the best of our knowledge, there is no data indicating that any active component of EMD reduces epithelial cell viability. The present study examines the impact of commercial lyophilized EMD, porcine recombinant amelogenin (prAMEL; $21.3 \mathrm{kDa}$ ) and tyrosine-rich amelogenin peptide (TRAP) on the adherence, proliferation and migration of human epithelial cells in real-time. The tongue carcinoma cell line SCC-25 was stimulated with EMD, porcine recombinant AMEL and TRAP, at concentrations of 12.5, 25 and $50 \mu \mathrm{g} / \mathrm{ml}$. Cell adherence, migration and proliferation were monitored in real-time using the xCELLigence system. No significant effects of EMD on the morphology, adhesion, proliferation and migration of SCC-25 cells were observed. However, porcine recombinant AMEL had a dose-dependent inhibitory effect on SCC-25 cell proliferation and migration. Predominantly, no notable differences were found between control and TRAP-treated cells in terms of cell adhesion and migration, a decrease in proliferation was observed, but this was not statistically significant. EMD and its active components do not increase the tongue cancer cell viability.
\end{abstract}

Correspondence to: $\mathrm{Dr}$ Marzena Wyganowska-Swiatkowska, Department of Conservative Dentistry and Periodontology, Collegium Stomatologicum, Poznań University of Medical Sciences, 70 Bukowska Street, 60-812 Poznań, Poland

E-mail: marzena.wyganowska@periona.pl

Professor Jerzy Jankun, Urology Research Center, Department of Urology, College of Medicine and Life Sciences, University of Toledo, 3000 Arlington Avenue, Toledo, OH 43614, USA

E-mail: jerzy.jankun@utoledo.edu

Key words: enamel matrix derivative, amelogenin, tyrosine-rich amelogenin peptide, epithelial cells

\section{Introduction}

Regeneration of periodontal tissue requires the exclusion of the epithelium and, in some cases, the gingival connective tissue from the root surface. In addition, previous studies (1-3) strongly support the hypothesis that enamel matrix proteins (EMPs), known for their impact on the structural organization of tooth enamel, may serve an important role in periodontal tissue formation (1). It is believed that enamel matrix derivative (EMD), the active component of Emdogain (Straumann), has odontogenic effects through inducing the proliferation and differentiation of connective tissue progenitor cells, stimulating bone growth and arresting gingival epithelial cell migration $(2,3)$.

EMD is comprised primarily of amelogenins (AMELs), a family of proline-rich peptides synthesized from the AMEL gene by alternative splicing and post-translational modifications. This family includes full-length AMEL (25 kDa), which is processed into a $20 \mathrm{kDa}$ protein, and then into a tyrosine-rich AMEL peptide (TRAP) and a leucine-rich AMEL peptide (LRAP) (4,5). Only a small number of studies have directly described the effect of EMD and full-length recombinant AMEL in vitro (6-8). Furthermore, alternatively spliced products and degraded forms of AMEL have biochemical properties that are distinct from full-length AMEL that are critical for function $(9,10)$, as well as between amelogenins with different molecular mass (11). Previous studies that have analyzed the influence of EMD on gingival epithelial cells are rare and the results ambiguous. A number of studies have demonstrated that EMD inhibits epithelial cell proliferation (12-15), while another indicated no effect (16) and another observed acceleration of epithelialization following EMD stimulation (17). Moreover, it is unclear which component of EMD is a direct inhibitor of epithelial cell growth. In previous studies, full-length recombinant AMEL was indicated to be the active component $(18,19)$.

The aim of present study was to investigate the influence of commercial lyophilized EMD, porcine recombinant prAMEL and TRAP on the adherence, proliferation and migration of human epithelial cells. Real-time cell analysis (RTCA; xCELLigence) was used to facilitate label-free and 
operator-independent investigation of cell behavior, through monitoring the cells in physiologically relevant conditions.

\section{Materials and methods}

Experimental proteins. Lyophilized EMD was provided by the Straumann AG Institute (Basel, Switzerland). Porcine recombinant AMEL (49 KDa) and TRAP (5.3 kDa) were synthesized, as described below. Cells were stimulated with protein extracts of $12.5,25$ and $50 \mu \mathrm{g} / \mathrm{ml}$.

\section{Porcine recombinant AMEL synthesis}

Construction of $p$ Gex4T-1-AMEL-GST. AMEL protein was provided by BLIRT S.A. (Gdańsk, Poland). The protein sequence of Sus scrofa AMEL was obtained from the UniProt database (accession no. Q861X0; uniprot.org/). This sequence, with an added glutathione S-transferase (GST) tag to increase protein solubility, is the following: ENFLYQGSMPLPPHPGHPGYINFYEDLYLEAIRIDRTAF VLTPLKWYQNMIRHPYTSYGYEPMGGWLHHQIIPVVS QQTPQSHALQPHHHIPMVPAQQPGIPQQPMMPLPGQH SMTPTQHHQPNLPLPAQQPFQPQPVQPQPHQPLQPQSP MHPIQPLLPQPPLPPMFSMQSLLPDLPLEAWPAT. The amelogenin construct contains prAMEL (21.3 kDa) and GST, yielding a molecular mass of $\sim 49 \mathrm{kDa}$.

The DNA sequence encoding the AMEL-GST protein was synthesized using the GeneArt service (Thermo Fisher Scientific, Inc.; Waltham, MA, USA). The sequence obtained was cloned into the pGex4T-1 vector (Addgene, Inc., Cambridge, MA USA) with NdeI and BamHI enzymes. The pGex4T-1-AMEL-GST construct was transformed into ArcticExpress (DE3) E. coli (Agilent Technologies, Inc., Santa Clara, CA, USA) using a chemical method. Plasmid DNA was added to $100 \mu \mathrm{l}$ competent cells on ice. The whole mixture was incubated on ice for $30 \mathrm{~min}$. The bacteria were shocked at $42^{\circ} \mathrm{C}$ and cooled on ice. lysogeny broth (LB) medium was added and the culture was grown at $37^{\circ} \mathrm{C}$ for $45 \mathrm{~min}$. The transformation mix was transferred on LB agar supplemented with ampicillin $(100 \mu \mathrm{g} / \mathrm{ml})$. The resulting clones were sequenced using an automated ABI Prism 3130xl Genetic Analyzer (Applied Biosystems; Thermo Fisher Scientific, Inc.) to confirm that cloning had been performed correctly. The amelogenin construct included amelogenin (21.3 kDa) and GST, yielding a final molecular mass of $43 \mathrm{kDa}$.

Overexpression of AMEL-GST in E. coli. ArcticExpress (DE3) $E$. coli containing the pGex4T-1-AMEL-GST construct were cultured overnight in LB media, supplemented with ampicillin $(100 \mu \mathrm{g} / \mathrm{ml})$ and gentamicin $(40 \mu \mathrm{g} / \mathrm{ml})$. Cultures were then diluted to a 1:100 ratio in the same media and cultured at $30^{\circ} \mathrm{C}$ until they reached an optical density reading of 0.6 at a wavelength of $600 \mathrm{~nm}$. The cultures were then cooled to $10^{\circ} \mathrm{C}$ and protein expression induced with $0.1 \mathrm{mM}$ isopropyl $\beta$-D-1-thiogalactopyranoside (IPTG). Cultivation was performed for $\sim 40 \mathrm{~h}$, prior to centrifugation at 3,500 x $\mathrm{g}$ for $30 \mathrm{~min}$ at $4^{\circ} \mathrm{C}$ (Heraeus Multifuge $3 \mathrm{~S}-\mathrm{R}$; Thermo Fisher Scientific, Inc.). And freezing of the resulting pellet.

Purification of the AMEL-GST fusion protein. The cell pellet $(\sim 15 \mathrm{~g})$ was suspended in $200 \mathrm{ml}$ of buffer A (50 mM Tris, $150 \mathrm{mM} \mathrm{NaCl}, 1 \mathrm{mM}$ EDTA, 1 mM DTT, pH 8), with protease inhibitor (1:100; P8340; Sigma-Aldrich; Merck Millipore, Darmstadt, Germany) lysed by sonication (10 times for $20 \mathrm{sec}$, $60 \mathrm{sec}$ rest, with total energy $200 \mathrm{~J} / \mathrm{ml}$ ) and the resulting lysate centrifuged at $3,500 \times \mathrm{g}$ for $30 \mathrm{~min}$ at $4^{\circ} \mathrm{C}$. As expected, most protein remained in the soluble fraction. Following centrifugation the protein was bound via its GST tag to a $5 \mathrm{ml}$ conditioned Glutathione Sepharose 4B (GE Healthcare Bio-Sciences AB, Uppsala, Sweden) for $2 \mathrm{~h}$ at $4^{\circ} \mathrm{C}$, rinsed twice with buffer $\mathrm{A} 4 \mathrm{X}$ column volume (CV) and eluted with buffer B (50 mM Tris, $50 \mathrm{mM} \mathrm{NaCl}, 20 \mathrm{mM}$ GSH, pH 8) 3x1.5 CV. The fractions obtained were analyzed by $4-12 \%$ SDS-PAGE to confirm the presence of AMEL and the quantity from images of the gels analyzed using TotalLab Quant 1.2 software (Cleaver Scientific Ltd., Warwickshire, United Kingdom) to determine the purity. Protein concentration was determined by the Bradford assay (Thermo Fisher Scientific, Inc.) and a NanoDrop instrument (Thermo Fisher Scientific, Inc.).

Lyophilization of the AMEL-GST fusion protein. AMEL-GST and GST were lyophilized using the freeze-dry technique. Proteins $(1 \mathrm{mg})$ in buffer A were aliquoted, frozen in liquid nitrogen and lyophilized overnight.

Reconstitution of the AMEL-GST fusion protein. Lyophilized AMEL-GST and GST were reconstituted in $1 \mathrm{ml}$ of buffer A to concentration of $1 \mathrm{mg} / \mathrm{ml}$. Reconstituted samples were centrifuged at 3,500 x $\mathrm{g}$ for $30 \mathrm{~min}$ at $4^{\circ} \mathrm{C}$ to remove any aggregated protein and separated by $4-12 \%$ SDS-PAGE to confirm reconstitution. Samples of AMEL-GST and GST were analyzed using the Bradford assay to confirm a concentration of $1 \mathrm{mg} / \mathrm{ml}$ and estimate the quantity of protein lost during reconstitution. Protein concentration prior to lyophilization and following reconstitution was $1 \mathrm{mg} / \mathrm{ml}$, indicating that no protein was lost.

\section{TRAP synthesis}

Construction of pET-22b-TRAP. A TRAP gene construct was obtained by polymerase chain reaction (PCR) amplification of the clone containing human AMEL cDNA using the following modified primers: Forward, 5'-TTT CAT ATG CAT CAC CAT CAC CAT CAC GAT GAC GAT GAC AAG ATG CCT CTA CCA CCT CAT CC-3' and reverse, 5'-TTT AAG CTT CAC CAT CCA CCC ATG GGT TCG TAC CCA TAG GAA GTG TAC GGA TGT CTT ATC ATG TTC TG-3'. Human AMEL cDNA clone was used as a template and modified primers converted the human TRAP coding sequence to the pig coding sequence of TRAP. These were capable of converting human TRAP coding sequence to pig coding sequence of TRAP, and contained a histidine tag and enterokinase recognition site. PCR was performed in a $25-\mu 1$ total reaction volume containing 5 ng plasmid DNA (human AMEL cDNA clone), 1X KAPA2G Robust HotStart DNA Polymerase (KK5702; Robust HotStart ReadyMix PCR kit; Kapa Biosystems, Inc., Wilmington, MA, USA) and $0.125 \mu \mathrm{M}$ of each primer. PCR thermal cycling conditions were as follows: 35 cycles of $30 \mathrm{sec}$ at $94^{\circ} \mathrm{C} ; 30 \mathrm{sec}$ at $58^{\circ} \mathrm{C}$; and $45 \mathrm{sec}$ at $72^{\circ} \mathrm{C}$. Subsequently, the PCR product was purified using a StrataPrep PCR Purification kit (400773; Agilent Technologies, Inc.) and sequenced using an automated 3130xl Genetic Analyzer (Applied Biosystems; Thermo Fisher Scientific, Inc.) to confirm correct cloning. The TRAP fragment was digested with $N d e \mathrm{I}$ and HindIII enzymes and ligated into 
the pET-22b(+) expression vector (Novagen; Merck \& Co., Inc., Whitehouse Station, NJ, USA) digested with the same endonucleases.

General procedures of handling DNA were performed according to Sambrook and Russel (20). Plasmid DNA was isolated using the StrataPrep Plasmid Miniprep kit (400761; Agilent Technologies, Inc.). PCR reagents, restriction enzymes and T4DNA ligase were purchased from Kapa Biosystems, Inc., (Wilmington, MA, USA), Thermo Fisher Scientific, Inc., and New England Biolabs, Inc., (Ipswich, MA, USA), respectively.

TRAP overexpression in E. coli. This construct was transformed into Rosetta 2 (DE3) pLysS E. coli (Novagen; Merck \& Co., Inc.) using a chemical method. Plasmid DNA was added to $100 \mu \mathrm{l}$ competent cells on ice. The whole mixture was incubated on ice for $30 \mathrm{~min}$. The bacteria were shocked at $42^{\circ} \mathrm{C}$ and cooled on ice. $\mathrm{LB}$ medium was added and culture was grown at $37^{\circ} \mathrm{C}$ for $45 \mathrm{~min}$. The transformation mix was transferred onto LB agar supplemented with ampicillin $(100 \mu \mathrm{g} / \mathrm{ml})$ and chloramphenicol (34 $\mu \mathrm{g} / \mathrm{ml}$ ). E. coli was routinely grown overnight at $37^{\circ} \mathrm{C}$, with standard antibiotic plate selection performed according to the manufacturer's instructions. Transformed $E$. coli were grown overnight in LB media supplemented with ampicillin $(100 \mu \mathrm{g} / \mathrm{ml})$ and chloramphenicol $(34 \mu \mathrm{g} / \mathrm{ml})$. Cultures were then diluted in a 1:100 ratio in the same media and cultured at $37^{\circ} \mathrm{C}$ until they reached an optical density reading of between 0.6 and 0.8 at a wavelength of $600 \mathrm{~nm}$. Then, protein expression was induced with $1 \mathrm{mmol} / \mathrm{l}$ IPTG and cultures were grown for $16 \mathrm{~h}$ at $37^{\circ} \mathrm{C}$.

Immobilized metal affinity chromatography of TRAP. Pellets were collected by centrifugation at 3,500 x $g$ for $30 \mathrm{~min}$ at $4{ }^{\circ} \mathrm{C}$ (Heraeus Multifuge 3 S-R; Thermo Fisher Scientific, Inc.). Pellets were suspended in $2 \mathrm{ml}$ of modified phosphate buffer solution $(50 \mathrm{mmol} / 1$ phosphate buffer disodium hydrogen phosphate and potassium dihydrogen phosphate, $\mathrm{pH} 8.0,300 \mathrm{mmol} / 1$ $\mathrm{NaCl}, 10 \%$ glycerol) and disrupted using a $10 \mathrm{ml}$ tissue grinder at $4^{\circ} \mathrm{C}$. The resulting lysate was centrifuged at $14,000 \times \mathrm{g}$ for $20 \mathrm{~min}$ at $4^{\circ} \mathrm{C}$. The supernatant from this was bound overnight at $4^{\circ} \mathrm{C}$ onto $2 \mathrm{ml}$ of cobalt resin (TALON Metal Affinity Resin; Clontech; Takara Biotechnology Co., Ltd., Dalian, China) equilibrated with phosphate buffer. Then, the suspension was placed in a PD-10 column (Sigma-Aldrich, St. Louis, MO, USA) and washed with $30 \mathrm{ml}$ of phosphate buffer. Unbound proteins were washed away using a stepwise $\mathrm{pH}$ gradient consisting of $10 \mathrm{ml}$ of phosphate buffer at $\mathrm{pH} 7.0,10 \mathrm{ml}$ of phosphate buffer at $\mathrm{pH} 6.0$ and $10 \mathrm{ml}$ of phosphate buffer at $\mathrm{pH}$ 5.7. The recombinant protein was eluted with $\mathrm{pH} 6.0$ phosphate buffer, where $2 \mathrm{ml}$ fractions were collected and frozen at $-20^{\circ} \mathrm{C}$. Samples were subjected to $16 \%$ SDS-PAGE and stained with Coomassie Brilliant Blue to visualize proteins. The concentration of purified protein was measured using the Bradford method and found a yield of $\sim 4.7 \mathrm{mg} / \mathrm{ml}$.

Cell culture. All experiments were performed on the human tongue squamous cell carcinoma cell line (SCC-25; cat. no. CRL-1628; American Type Culture Collection, Manassas, VA, USA). SCC-25 cells were transferred under aseptic conditions from freezing medium [Dulbecco's modified Eagle medium/Nutrient Mixture F-12 (DMEM/F12), 10\% fetal bovine serum (FBS) and 10\% dimethyl sulfoxide (all Gibco; Thermo Fisher Scientific, Inc.), and $400 \mathrm{ng} / \mathrm{ml}$ of hydrocortisone], to a $90 \mathrm{~mm}$ sterile petri dish (Sarstedt AG \& Co., Nümbrecht, Germany) containing $10 \mathrm{ml}$ of growth medium [DMEM/F12, $10 \% \mathrm{FBS}, 100 \mu \mathrm{g} / \mathrm{ml}$ penicillin, $100 \mu \mathrm{g} / \mathrm{ml}$ streptomycin and 2 mmol/l L-glutamine (all Gibco; Thermo Fisher Scientific, Inc.), and $400 \mathrm{ng} / \mathrm{ml}$ of hydrocortisone]. Cells were grown at $37^{\circ} \mathrm{C}$, under $5 \% \mathrm{CO}_{2}$ and at $100 \%$ relative humidity. Cells were cultured until $90 \%$ confluency, washed with phosphate buffered saline and trypsinized $(0.25 \%$ trypsin containing $0.01 \%$ EDTA). Following $5 \mathrm{~min}$ incubation at room temperature, complete growth medium was added at a ratio of 1:10, and the cell suspension was transferred to new petri dishes.

Cell adherence and monitoring. Cell adherence and proliferation was monitored in real-time using the $\mathrm{xCELLigence}$ system and E-Plate 96 insert (ACEA Biosciences, Inc., San Diego, CA, USA). Instrument measures the electrical resistance of the sensor electrodes that is proportional to the number of cells attached to the sensors, which allows real time measurements by probing cell growth at different time intervals. The electrical impedance value of each well was automatically monitored by the xCELLigence system and expressed as a cell index (CI) value. Each experiment was performed five times. The external control plate contained cells that were not exposed to the experimental proteins.

For cell adherence measurements, after reaching $90 \%$ confluency, SCC-25 cells were passaged with $0.25 \%$ trypsin solution and seeded into wells of the E-plate 96 at 10,000 cells/well. Immediately, 96 wells were stimulated with the protein extracts (EMD, AMEL and TRAP at final concentrations of $12.5,25$ and $50 \mu \mathrm{g} / \mathrm{ml}$, respectively), released by the metallic alloy material, and monitored every $15 \mathrm{~min}$ for $14 \mathrm{~h}$.

For cell proliferation measurements, after reaching confluence, SCC-25 cells were passaged with $0.25 \%$ trypsin and seeded into wells of the E-plate 96 at 10,000 cells/well. Then, cells were left to obtain cell a CI value equal to $\sim 1$. Afterwards, cells were treated with EMD, prAMEL and TRAP $(12.5,25$ and $50 \mu \mathrm{g} / \mathrm{ml}$, respectively), released by the metallic alloy material, and monitored every $15 \mathrm{~min}$ for $48 \mathrm{~h}$. Evaluation was performed 12, 24, 48, 60 and $77 \mathrm{~h}$ after stimulation.

Monitoring of cell migration. The rate of cell migration was monitored in real-time with the xCELLigence system and the CIM-plate 16 insert (ACEA Biosciences, Inc.). Cells were passaged and placed in the upper chamber of CIM-plate 16 in FBS-free media. The lower chamber of the plate contained $160 \mu 1$ of media with $10 \%$ of FBS as an attractant. Cell migration was measured by electrodes located between the lower and upper chambers. Immediately following seeding at 20,000 cells/well, cells were treated with EMD, prAMEL and TRAP $(12.5,25$ and $50 \mu \mathrm{g} / \mathrm{ml}$, respectively), and monitored every $15 \mathrm{~min}$ for $49 \mathrm{~h}$. The control plate contained cells not exposed to the proteins.

Statistical analysis. Statistical analysis was performed using Statistica software (version 10; StatSoft, Inc., Tulsa, OK, USA). The Shapiro-Wilk test of normality was used on continuous variables. The results are described as the mean \pm standard 

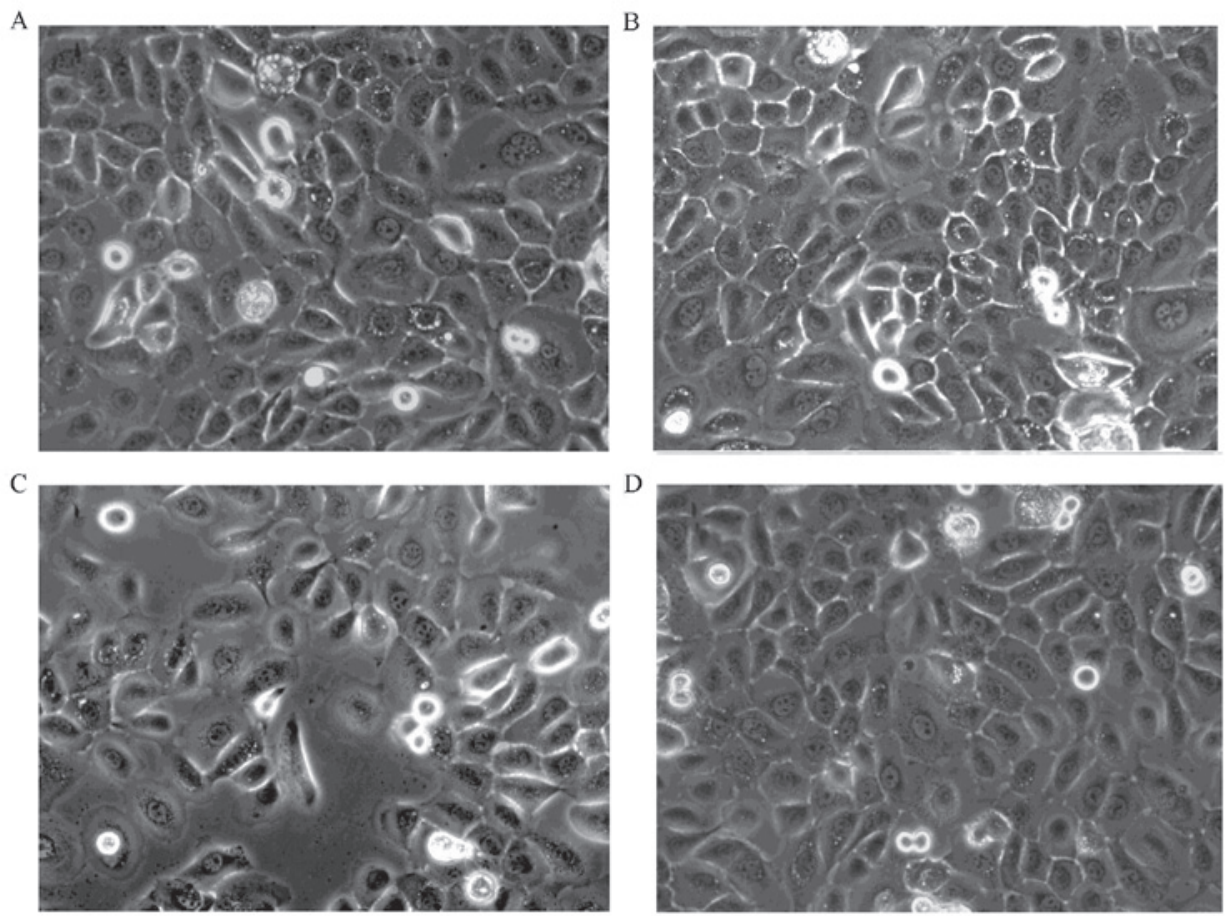

Figure 1. No difference was observed in SCC-25 cell morphology prior to and following stimulation with enamel matrix derivative (EMD), porcine recombinant AMEL and tyrosine-rich AMEL peptide (TRAP). (A) Untreated SCC-25 control cells were characterized by a spindle-like shape, which became more circular with increasing cell density. No difference in morphology was observed between the control cells and cells following (B) $50 \mu \mathrm{g} / \mathrm{ml} \mathrm{EMD,} \mathrm{(C)} 50 \mu \mathrm{g} / \mathrm{ml}$ prAMEL and (D) $50 \mu \mathrm{g} / \mathrm{ml}$ TRAP stimulation. Images were captured at a magnification of $\mathrm{x} 40$.

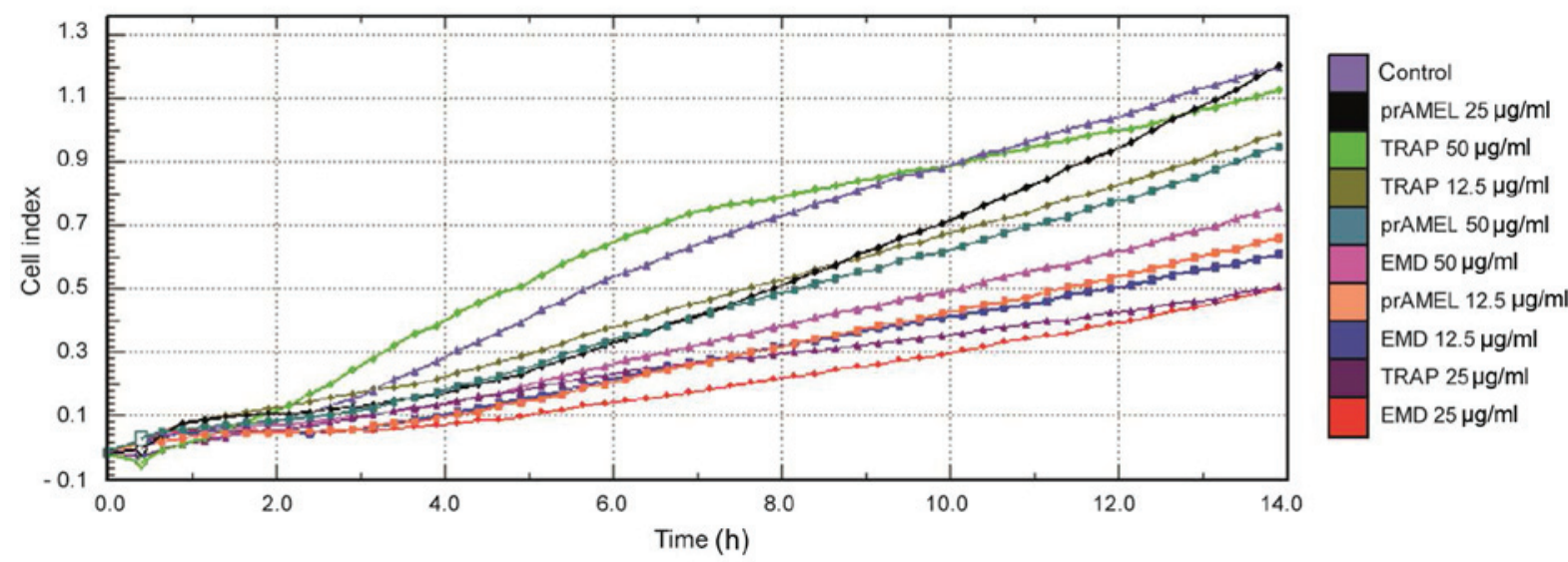

Figure 2. Effect of enamel matrix proteins on the rate of adherence of SCC- 25 cells. The rate of SCC- 25 cells adherence was monitored between 0 and $14 \mathrm{~h}$, in real-time using the xCELLigence system, following stimulation with EMD, porcine recombinant prAMEL or TRAP. prAMEL, porcine recombinant amelogenin; TRAP, tyrosine-rich AMEL peptide; EMD, enamel matrix derivative.

deviation. One-way analysis of variance with the multiple comparisons Tukey's test was applied. $\mathrm{P}<0.05$ was considered to indicate a statistically significant difference.

\section{Results}

Cell morphology. None of the analyzed proteins affected SCC-25 cell morphology, regardless of the dose (Fig. 1). SCC-25 cells, characterized by a spindle-like shape. Only changes to a more circular shape with increasing cell density were observed. In addition, characteristic proliferation in clusters was observed (Fig. 1).
Cell adherence. The effect of experimental proteins on SCC-25 cell adhesion was monitored over $14 \mathrm{~h}$ in real-time. A representative graph comparing the rate of cell adherence, in terms of CI, when incubated with EMD, prAMEL or TRAP protein is shown in Fig. 2. No significant difference in cell adherence was observed among all the groups, regardless of dose (Table I).

Cell proliferation. Cell proliferation was monitored using RTCA over a period of $77 \mathrm{~h}$ after EMD, prAMEL or TRAP stimulation. A representative graph comparing the rate of CI of SCC-25 cells is shown in Fig. 3. No significant difference 
Table I. Effect of EMPs on the rate of adherence of SCC-25 cells.

\begin{tabular}{lccc}
\hline & \multicolumn{3}{c}{ Cell index value mean \pm standard deviation } \\
\cline { 2 - 4 } EMP added, $\mu \mathrm{g} / \mathrm{ml}$ & 4-h incubation & 8-h incubation & 12-h incubation \\
\hline Control & $0.80 \pm 0.9$ & $1.49 \pm 1.3$ & $1.94 \pm 1.6$ \\
EMD, 12.5 & $0.57 \pm 0.5$ & $0.93 \pm 0.8$ & $1.22 \pm 0.9$ \\
EMD, 25 & $0.56 \pm 0.5$ & $0.94 \pm 0.8$ & $1.23 \pm 1.0$ \\
EMD, 50 & $0.55 \pm 0.3$ & $0.99 \pm 0.4$ & $1.36 \pm 0.4$ \\
prAMEL, 12.5 & $0.53 \pm 0.4$ & $0.91 \pm 0.6$ & $1.24 \pm 0.7$ \\
prAMEL, 25 & $0.62 \pm 0.2$ & $1.14 \pm 0.3$ & $1.59 \pm 0.3$ \\
prAMEL, 50 & $0.70 \pm 0.3$ & $1.25 \pm 0.4$ & $1.67 \pm 0.5$ \\
TRAP, 12.5 & $0.77 \pm 0.5$ & $1.28 \pm 0.8$ & $1.66 \pm 0.9$ \\
TRAP, 25 & $0.52 \pm 0.4$ & $0.84 \pm 0.6$ & $1.08 \pm 0.7$ \\
TRAP, 50 & $1.07 \pm 0.6$ & $1.65 \pm 0.7$ & $1.95 \pm 0.8$ \\
P-value & $>0.05$ & $>0.05$ & $>0.05$ \\
\hline
\end{tabular}

Cell index values were monitored using the xCELLigance system. Results are from three repeats. No significant differences were detected between the groups. EMP, enamel matrix protein; EMD, enamel matrix derivative; prAMEL, porcine recombinant amelogenin; TRAP, tyrosine-rich amelogenin peptide.

Table II. Effect of EMPs on the rate of proliferation of SCC-25 cells.

\begin{tabular}{lccc}
\hline & \multicolumn{3}{c}{ Cell index value mean \pm standard deviation } \\
\cline { 2 - 4 } EMP added, $\mu \mathrm{g} / \mathrm{ml}$ & 12-h incubation & 24-h incubation & 48-h incubation \\
\hline Control & $3.9 \pm 0.9$ & $5.0 \pm 1.3$ & $7.2 \pm 0.6$ \\
EMD, 12.5 & $5.6 \pm 1.1$ & $6.8 \pm 1.1$ & $7.0 \pm 0.1$ \\
EMD, 25 & $5.4 \pm 0.8$ & $6.7 \pm 0.5$ & $7.1 \pm 0.1$ \\
EMD, 50 & $4.4 \pm 0.1$ & $5.7 \pm 0.1$ & $7.8 \pm 0.4$ \\
prAMEL, 12.5 & $3.0 \pm 0.5$ & $3.7 \pm 0.4$ & $5.1 \pm 0.3$ \\
prAMEL, 25 & $4.5 \pm 1.2$ & $5.0 \pm 0.8$ & $5.2 \pm 0.9$ \\
prAMEL, 50 & $3.5 \pm 1.3$ & $4.4 \pm 0.7$ & $4.9 \pm 0.9$ \\
TRAP, 12.5 & $3.6 \pm 0.7$ & $4.4 \pm 0.9$ & $5.6 \pm 1.1$ \\
TRAP, 25 & $5.1 \pm 0.3$ & $6.2 \pm 0.4$ & $6.5 \pm 0.3$ \\
TRAP, 50 & $4.0 \pm 0.4$ & $5.0 \pm 0.4$ & $6.2 \pm 0.2$ \\
P-value & 0.07 & $0.02^{\mathrm{a}}$ & $0.005^{\mathrm{b}}$ \\
\hline
\end{tabular}

Cell index values were monitored using the xCELLigance system. Results are from three repeats. EMP, enamel matrix protein; EMD, enamel matrix derivative; prAMEL, porcine recombinant amelogenin; TRAP, tyrosine-rich amelogenin peptide. P-value calculated from one-way analysis of the variance. ${ }^{\mathrm{a}}<0.05$ between prAMEL $(12.5 \mu \mathrm{g} / \mathrm{ml})$ and EMD and TRAP; ${ }^{\mathrm{b}} \mathrm{P}<0.05$ between all concentrations of prAMEL and EMD and TRAP.

in the rate of proliferation was observed after 12 -h incubation (Table II). RTCA analysis performed after 24-h incubation showed a significant decrease of CI in prAMEL $(12.5 \mu \mathrm{g} / \mathrm{ml})$ compared with cells stimulated with EMD $12.5 \mu \mathrm{g} / \mathrm{ml}(\mathrm{P}=0.02)$ and $25 \mu \mathrm{g} / \mathrm{ml}$-stimulated cells $(\mathrm{P}=0.02)$. Moreover, all doses of AMEL $(12.5,25$ and $50 \mu \mathrm{g} / \mathrm{ml})$ administered for 48 -h caused a significant decrease in the proliferation rate in comparison with both control cells ( $\mathrm{P}<0.001$ for all doses) and all EMD doses $(\mathrm{P}<0.001$ for all comparisons; Fig. 4) and EMD (50 $\mu \mathrm{g} / \mathrm{ml})$-stimulated cells ( $\mathrm{P}=0.005$; Fig. 4).
Cell migration. Regardless of the type of ligand, dose and time following stimulation, no significant differences in SCC-25 cell migration were observed (Table III). A graph showing the rate of migration of SCC-25 cells when incubated with EMD, prAMEL or TRAP protein is shown in Fig. 5.

\section{Discussion}

Previous studies on the effects of EMD, conducted on a variety of research models, have been inconclusive $(21,22)$. A number 
Table III. Effect of EMPs on the rate of migration of SCC-25 cells.

Cell index value mean \pm standard deviation

\begin{tabular}{lccc} 
EMP added,$\mu \mathrm{g} / \mathrm{ml}$ & 12-h incubation & 24-h incubation & 28-h incubation \\
\cline { 2 - 4 } Control & $1.4 \pm 2.1$ & $1.8 \pm 2.0$ & $2.6 \pm 1.8$ \\
EMD, 12.5 & $2.0 \pm 1.6$ & $2.2 \pm 1.8$ & $3.2 \pm 2.6$ \\
EMD, 25 & $3.4 \pm 2.6$ & $3.7 \pm 2.6$ & $3.8 \pm 1.7$ \\
EMD, 50 & $3.7 \pm 3.0$ & $3.9 \pm 3.1$ & $3.7 \pm 2.7$ \\
prAMEL, 12.5 & $1.1 \pm 1.4$ & $2.0 \pm 1.8$ & $3.9 \pm 2.4$ \\
prAMEL, 25 & $1.3 \pm 1.8$ & $2.1 \pm 1.4$ & $3.9 \pm 2.6$ \\
prAMEL, 50 & $0.9 \pm 0.9$ & $2.0 \pm 1.1$ & $4.0 \pm 2.0$ \\
TRAP, 12.5 & $1.7 \pm 2.1$ & $2.5 \pm 2.3$ & $3.7 \pm 2.0$ \\
TRAP, 25 & $2.1 \pm 2.0$ & $3.3 \pm 2.0$ & $4.9 \pm 0.4$ \\
TRAP, 50 & $2.1 \pm 2.5$ & $2.9 \pm 2.1$ & $4.0 \pm 2.2$ \\
P-value & $>0.05$ & $>0.05$ & $>0.05$ \\
\hline
\end{tabular}

Cell index values were monitored using the xCELLigance system. Results are from three repeats. No significant differences were detected between the groups. EMP, enamel matrix protein; EMD, enamel matrix derivative; prAMEL, porcine recombinant amelogenin; TRAP, tyrosine-rich amelogenin peptide.

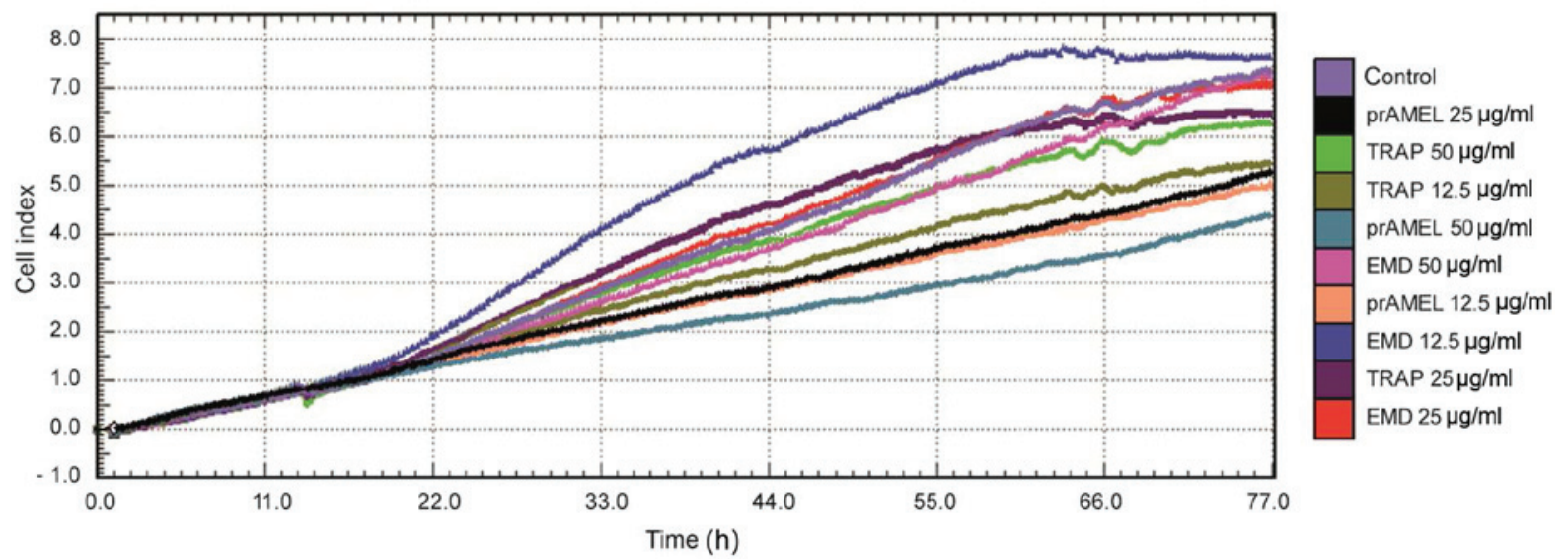

Figure 3. Effect of enamel matrix proteins on the rate of proliferation of SCC-25 cells. SCC-25 cells were incubated with EMD, porcine recombinant prAMEL or TRAP for $77 \mathrm{~h}$, and the rate of proliferation was monitored in real-time using the xCELLigence system. EMD, enamel matrix derivative; TRAP, tyrosine-rich amelogenin peptide; prAMEL, porcine recombinant AMEL.

of ambiguities have made it hard to compare the results between studies and have impeded the characterization of the functions of the different components of EMD. Firstly, previous in vitro studies have used various cell types (epithelial, tongue carcinoma, gingival fibroblast, periodontal ligament, bone marrow-mesenchymal stem cells) obtained from different species (such as, rat, pig and human) (18,19,21-24). Secondly, the studies used a number of different EMPs, such as commercial lyophilized EMD and different fractions isolated from it ( $<6 \mathrm{kDa}$, mainly TRAP; $>6 \mathrm{kDa}$, LRAP, sheathing peptides and the full-length AMEL) (21), or numerous recombinants, such as full-length AMEL (22) and chemically synthesized $5.3 \mathrm{kDa}$ TRAP (23). Furthermore, there are marked differences in the concentration of EMPs used; from between $10 \mathrm{ng} / \mathrm{ml}$ and $100 \mu \mathrm{g} / \mathrm{ml}$. Finally, different techniques were applied in order to measure the biological effects of the
EMPS. Conventional cell-based assays may be more prone to artifacts, due to considerable manipulation of the cell by labeling or over-expression of target or reporter proteins (25).

Numerous studies concerning the effects of EMD focus on periodontal tissue, including its stimulation $(14,15,24)$. These have shown that the effects of EMD are different in mesenchymal and epithelial cells $(14,18,19,24)$. Results concerning the influence of EMD on oral epithelial cells are particularly ambiguous; EMD was determined to have an anti-proliferative effect on epithelial cells $(12,13)$, but numerous clinicians have observed accelerated epithelial soft-tissue healing upon intrasurgical application of EMD (26-29). It has been suggested that EMD may induce alterations in malignant mucosal tissue, which implies that patients with pre-malignant or malignant mucosal lesions should not be treated with EMD (27). 


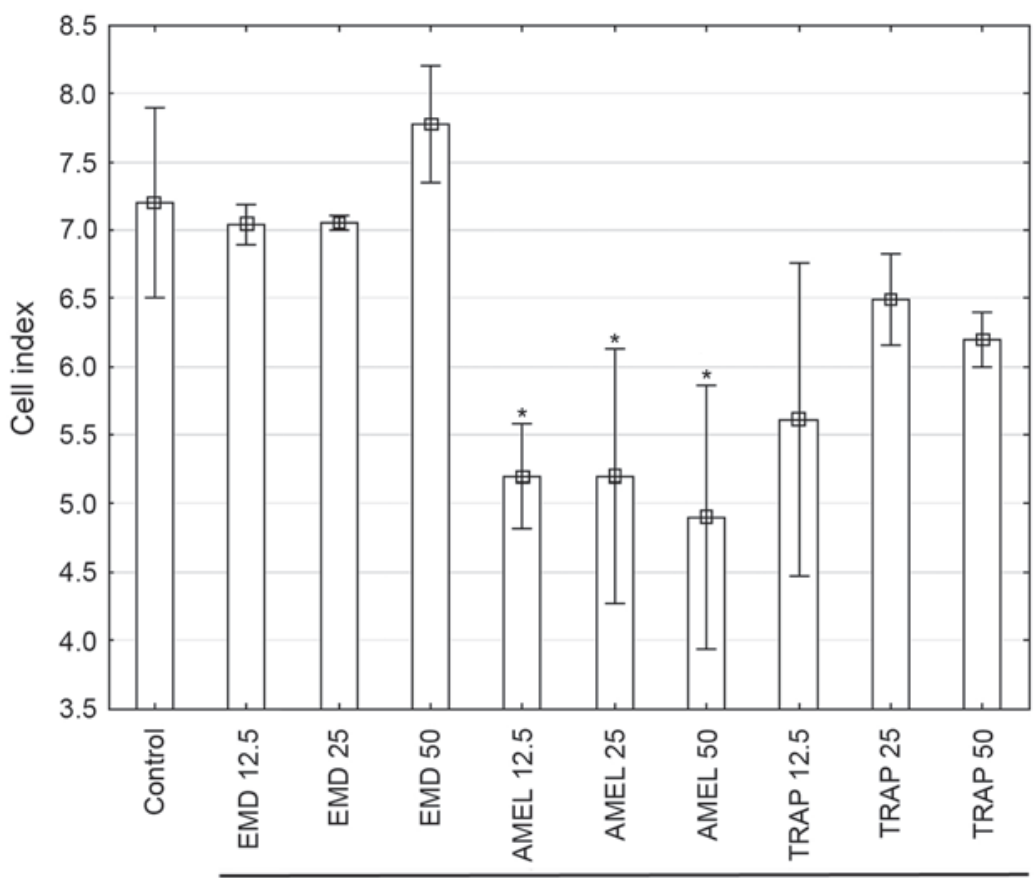

Enamel matrix protein added $(\mu \mathrm{g} / \mathrm{ml})$

Figure 4. Effect of enamel matrix proteins on the rate of proliferation of SCC-25 cells $48 \mathrm{~h}$ after stimulation. SCC- 25 cells were incubated with EMD, porcine recombinant AMEL or TRAP for $48 \mathrm{~h}$, and the rate of proliferation was monitored using the xCELLigence system. Results were obtained from 3 separate analyses and are expressed as the mean \pm standard deviation (error bars). ${ }^{*} \mathrm{P}<0.05$ vs. control and all EMD concentrations, as determined by one-way analysis of the variance with a post-hoc Tukey test.

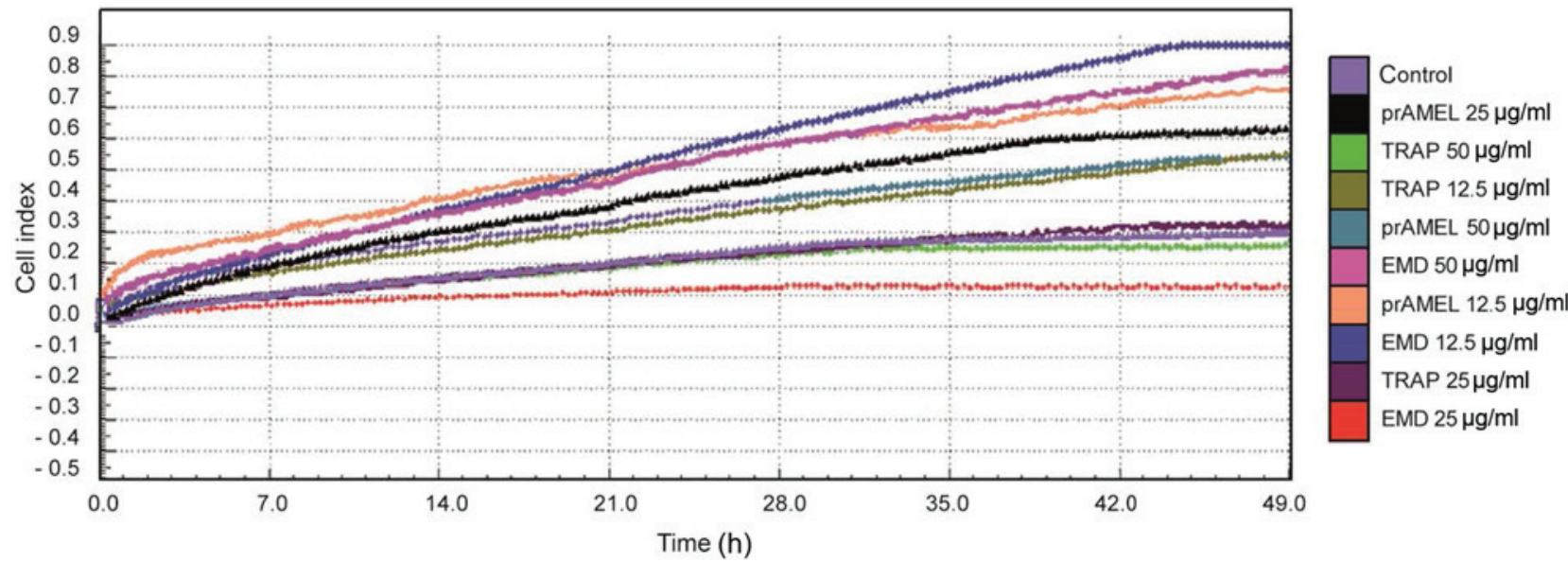

Figure 5. Effect of enamel matrix proteins on the rate of migration of SCC-25 cells. The rate of migration was monitored in real-time for $49 \mathrm{~h}$ (xCELLigence system) following incubation with EMD, porcine recombinant AMEL or TRAP. EMD, enamel matrix derivative; prAMEL, porcine recombinant amelogenin; TRAP, tyrosine-rich AMEL peptide.

The aim of the present study was to determine the influence of EMD, AMEL and TRAP on human tongue carcinoma cells using a cell-based, label-free and real-time platform technology (xCELLigence). Label-free technologies have the advantage of being non-invasive. The real-time monitoring of cells provides important information regarding their biological status, such as cell growth, arrest and morphological changes. The qualities of this system made it possible to obtain physiologically relevant results.

The results of the present study indicate that EMD does not influence the morphology of SCC-25 significantly. Kawase et al (13) observed that SCC-25 cell cultures treated with $100 \mu \mathrm{g} / \mathrm{ml}$ EMD for 3 days became more flattened and had a slightly lower cell density. In the present study, cells were stimulated with EMD at concentrations of 12.5, 25 and $50 \mu \mathrm{g} / 1$, which may explain the differences in the results obtained.

Real-time tests performed using the xCELLigence system indicate no significant effects of EMD on adhesion, proliferation and migration of SCC- 25 cells. These results contradict the observations of Kawase et al (13), that EMD (in a dose-dependent manner) inhibited oral epithelial cell division and concomitantly arrested cell cycling at the G1 phase, although no apoptosis was observed. Kawase et al (13) concluded that EMD acts as a cytostatic, rather than cytotoxic, agent on 
epithelial cells. In other studies the same group of researchers showed that EMD reduced DNA synthesis in a dose-dependent manner $(12,14)$. Evidence from the literature suggests that the suppression of epithelial cell growth observed may be mediated by transforming growth factor $\beta 1$ (TGF- $\beta 1$ ) (14). Porcine TGF- $\beta 1$ up-regulates p21 (WAF/CIP1) expression and inhibits epithelial proliferation (14). In addition, TGF- $\beta 1$ phosphorylates the mitogen-activated protein kinase (MAPK) family, similar to EMD. Anti-TGF- $\beta$ antibody completely blocks the up-regulation of p21 protein and anti-proliferative action by EMD or TGF- $\beta$ in epithelial cells (14). In addition, anti-TGF- $\beta$ antibody blocks other actions of EMD in epithelial cells, p38-MAPK and inhibition of DNA synthesis (14).

Anti-TGF- $\beta$ antibody blocks TGF- $\beta 1$ - and EMD-induced SMAD family member 2 (SMAD2) translocation (14). Kawase et al (14) concluded that TGF- $\beta 1$, as a principal bioactive factor in EMD, likely inhibits epithelial cell proliferation by a SMAD2-mediated, p21-dependent mechanism. Moreover, Kawase et al (12) showed that $50 \mu \mathrm{g} / \mathrm{ml}$ EMD promoted SCC-25 cell adherence and stimulated cytoskeletal actin polymerization. However, Laaksonen et al (30) did not confirm the inhibitory effects of EMD on tongue squamous cell carcinoma proliferation, no differences were found between the control and the EMD-treated (100 and $200 \mu \mathrm{g} / \mathrm{ml})$ cells after 12, 24, 48, 72 and $96 \mathrm{~h}$ of incubation. Furthermore, Gestrelius et al (16) did not observe any statistically significant changes in rat tongue epithelial cell proliferation after exposure to $100 \mu \mathrm{g} / \mathrm{ml}$ EMD. In addition, Mirastschijski et al (17) revealed significant epithelization after EMD treatment in vivo in rabbits. Moreover, a previous study indicated that EMD promotes re-epithelialization and neovascularization in full-thickness surgical wounds in rat oral mucosa (28). Maymon-Gil et al (29) observed that EMD had no effect on epithelial gap closure of an oral mucosa surgical wound in vivo in rats. The differences in the results of these studies are likely associated with the method of EMD application; directly on the wound, or underneath the soft tissues.

Previous studies conducted on cervical cancer cells indicated that EMD has an inhibitory effect on epithelial cells $(13,27)$. Lyngstadaas et al (15) showed that HeLa cells growing in the presence of EMD exhibited a highly increased intracellular level of cyclic adenosine monophosphate compared with controls. EMD primarily contains glycoproteins, and AMEL to non-AMEL proteins (such as, ameloblastin and enamelin) at a ratio of $29: 1$ (AMEL:rest of proteins) $(31,32)$. Full-length AMEL induces proliferation in periodontal cells, such as mesenchymal stem cells (33), cementoblasts (34), periodontal fibroblasts $(18,34)$ and gingival fibroblasts $(18)$.

The present study observed a dose-dependent inhibitory effect of porcine recombinant AMEL (21.3 kDa) on SCC-25 cell proliferation. These results are consistent with observations made by a previous study that indicated that recombinant AMEL inhibits the growth rate, adhesion and migration of gingival epithelial cells (18). Li et al (19) identified that recombinant $25 \mathrm{kDa}$ porcine AMEL (5, 10 and $20 \mu \mathrm{g} / \mathrm{ml})$ inhibited human gingival epithelial cell attachment, migration and growth rate in a time- and dose-dependent manner. In addition, a previous study demonstrated that recombinant AMEL inhibits epithelial cell proliferation in vitro. The results of Kuramitsu-Fujimoto et al (35) suggest that ameloblastin is the primary bioactive factor of EMD in regards to inhibition of epithelial cell proliferation. It has been suggested that EMPs, such as AMELs and ameloblastin, are required for enamel biomineralization and have synergistic cellular functions (36).

The present study examined the effects of recombinant $5.3 \mathrm{kDa}$ TRAP on SCC-25 cells. No significant differences were found between the control and TRAP-treated (12.5, 25 and $50 \mu \mathrm{g} / \mathrm{ml}$ ) cells in terms of adhesion, migration and proliferation. Villa et al (28) observed increased migration of epithelial cells following EMD treatment compared with recombinant TRAP stimulation in palatal wounds in rats. Numerous previous studies have analyzed the effect of the EMD protein fraction with a molecular weight of $\sim 5 \mathrm{kDa}$, which is presumably composed by TRAP $(4,5,37,38)$. These studies performed the following TRAP preparation methods: TRAP isolated from EMD; recombinant peptide TRAP; and synthetic TRAP, which resulted in different observations concerning their biological effects $(4,5,37,38)$. This suggests that the method of TRAP preparation may be an important factor in influencing its biological activity. Jonke et al (37) demonstrated that TRAP isolated from EMD and synthetic TRAP $(100 \mu \mathrm{g} / \mathrm{ml})$ significantly decreased human umbilical vein endothelial cell proliferation and viability. No statistically significant decrease in proliferation of TRAP-treated cells was observed in the present study, although this was recombinant TRAP, $50 \mu \mathrm{g} / \mathrm{ml}$ was the highest concentration used and was on different cell line. EMPs are conserved as well as the TRAP cleavage site in humans and other mammals (1), however, because EMD contains porcine AMELs, porcine AMEL and porcine TRAP were used in the present study to minimize any differences. To the best of our knowledge, no previous studies used a similar research model of TRAP synthesis, which impeded the verification of results obtained.

In conclusion, the aim of the present study was to investigate effects of EMD, porcine recombinant AMEL and TRAP on SCC-25 cells using a real-time cell analysis platform (xCELLigence). The results demonstrated that EMD and its active components did not increase the tongue cancer cell viability, and that porcine recombinant AMEL inhibited epithelial cell proliferation and migration. To the best of our knowledge, no previous EMD studies concerning SCC-25 cells were conducted with the use of real-time monitoring. Thus, differences between the results of the present study and those obtained by previous studies are likely due to differences in the measurement technique used and the structure of applied ligands (AMEL and/or EMD). The amelogenin construct was coding a protein with a mass of $21.3 \mathrm{kDa}$; however, a GST tag was added in order to increase the protein solubility. The final product used in the present research, comprising of amelogenin and GST, had a molecular mass of $49 \mathrm{kDa}$. The xCELLigence system enables better reproducibility than other instruments, which is an argument in favor of its use in real-time analysis of SCC-25 cells.

\section{References}

1. Fincham AG, Belcourt AB, Termine JD, Butler WT and Cothran WC: Amelogenins. Sequence homologies in enamel-matrix proteins from three mammalian species. Biochem J 211: 149-154, 1983.

2. Miron RJ, Caluseru OM, Guillemette V, Zhang Y, Gemperli AC, Chandad $\mathrm{F}$ and Sculean A: Influence of enamel matrix derivative on cells at different maturation stages of differentiation. PLoS One 8: e71008, 2013 
3. Miron RJ, Wei L, Yang S, Caluseru OM, Sculean A and Zhang Y: Effect of enamel matrix derivative on periodontal wound healing and regeneration in an osteoporotic model. J Periodontol 85: $1603-1611,2014$

4. Fincham AG, Belcourt AB, Termine JD, Butler WT and Cothran WC: Dental enamel matrix: Sequences of two amelogenin polypeptides. Biosci Rep 1: 771-778, 1981.

5. Fincham AG, Hu YY, Pavlova Z, Slavkin HC and Snead ML: Human amelogenins: Sequences of 'TRAP' molecules. Calcif Tissue Int 45: 243-250, 1989.

6. Grayson RE, Yamakoshi Y, Wood EJ and Agren MS: The effect of the amelogenin fraction of enamel matrix proteins on fibroblast-mediated collagen matrix reorganization. Biomaterials 27: 2926-2933, 2006.

7. Hoang AM, Klebe RJ, Steffensen B, Ryu OH, Simmer JP and Cochran DL: Amelogenin is a cell adhesion protein. J Dent Res 81: 497-500, 2002.

8. Matsuzawa M, Sheu TJ, Lee YJ, Chen M, Li TF, Huang CT, Holz JD and Puzas JE: Putative signaling action of amelogenin utilizes the Wnt/beta-catenin pathway. J Periodontal Res 44: 289-296, 2009.

9. Sun Z, Fan D, Fan Y, Du C and Moradian-Oldak J: Enamel proteases reduce amelogenin-apatite binding. J Dent Res 87: 1133-1137, 2008.

10. Tan J, Leung W, Moradian-Oldak J, Zeichner-David M and Fincham AG: Quantitative analysis of amelogenin solubility. J Dent Res 77: 1388-1396, 1998.

11. Yamakoshi Y: Porcine Amelogenin: Alternative splicing, proteolytic processing, protein-protein interactions, and possible functions. J Oral Biosci 53: 275-283, 2011.

12. Kawase T, Okuda K, Momose M, Kato Y, Yoshie H and Burns DM: Enamel matrix derivative (EMDOGAIN) rapidly stimulates phosphorylation of the MAP kinase family and nuclear accumulation of smad2 in both oral epithelial and fibroblastic human cells J Periodontal Res 36: 367-376, 2001.

13. Kawase T, Okuda K, Yoshie H and Burns DM: Cytostatic action of enamel matrix derivative (EMDOGAIN) on human oral squamous cell carcinoma-derived SCC25 epithelial cells. J Periodontal Res 35: 291-300, 2000

14. Kawase T, Okuda K, Yoshie H and Burns DM: Anti-TGF-beta antibody blocks enamel matrix derivative-induced upregulation of p21WAF1/cipl and prevents its inhibition of human oral epithelia cell proliferation. J Periodontal Res 37: 255-262, 2002.

15. Lyngstadaas SP, Lundberg E, Ekdahl H, Andersson C and Gestrelius S: Autocrine growth factors in human periodontal ligament cells cultured on enamel matrix derivative. J Clin Periodontol 28: 181-188, 2001.

16. Gestrelius S, Andersson C, Lidström D, Hammarström L and Somerman M: In vitro studies on periodontal ligament cells and enamel matrix derivative. J Clin Periodontol 24: 685-692, 1997.

17. Mirastschijski U, Konrad D, Lundberg E, Lyngstadaas SP, Jorgensen LN and Agren MS: Effects of a topical enamel matrix derivative on skin wound healing. Wound Repair Regen 12 100-108, 2004

18. Li X, Shu R, Liu D and Jiang S: Different effects of 25-kDa amelogenin on the proliferation, attachment and migration of various periodontal cells. Biochem Biophys Res Commun 394: $581-586,2010$

19. Li XT, Shu R, Song ZC and Zhou YB: The effects of recombinant porcine amelogenin on human gingival epithelial cells. Shanghai Kou Qiang Yi Xue 21: 257-261, 2012 (In Chinese).

20. Sambrook J and Russel DW: Molecular cloning a laboratory manual. Cold Spring Harbor Laboratory Press, New Yourk, Cold Spring Harbor Laboratory Press, 2001.

21. Amin HD, Olsen I, Knowles JC and Donos N: Differential effect of amelogenin peptides on osteogenic differentiation in vitro: Identification of possible new drugs for bone repair and regeneration. Tissue Eng Part A 18: 1193-1202, 2012.
22. Frasheri I,Ern C,Diegritz C,Hickel R,Hristov M and Folwaczny M: Full-length amelogenin influences the differentiation of human dental pulp stem cells. Stem Cell Res Ther 7: 10, 2016.

23. Amin HD, Olsen I, Knowles J, Dard M and Donos N: A tyrosine-rich amelogenin peptide promotes neovasculogenesis in vitro and ex vivo. Acta Biomater 10: 1930-1939, 2014.

24. Grandin HM, Gemperli AC and Dard M: Enamel matrix derivative: A review of cellular effects in vitro and a model of molecular arrangement and functioning. Tissue Eng Part B Rev 18: 181-202, 2012.

25. Xi B, Yu N, Wang X, Xu X and Abassi YA: The application of cell-based label-free technology in drug discovery. Biotechnol J 3: 484-495, 2008.

26. Sanz M, Tonetti MS, Zabalegui I, Sicilia A, Blanco J, Rebelo H, Rasperini G, Merli M, Cortellini P and Suvan JE: Treatment of intrabony defects with enamel matrix proteins or barrier membranes: Results from a multicenter practice-based clinical trial. J Periodontol 75: 726-733, 2004.

27. Laaksonen M, Sorsa T and Salo T: Emdogain in carcinogenesis: A systematic review of in vitro studies. J Oral Sci 52: 1-11, 2010.

28. Villa O, Wohlfahrt JC, Mdla I, Petzold C, Reseland JE, Snead ML and Lyngstadaas SP: Proline-rich peptide mimics effects of enamel matrix derivative on rat oral mucosa incisional wound healing. J Periodontol 86: 1386-1395, 2015.

29. Maymon-Gil T, Weinberg E, Nemcovsky C and Weinreb M: Enamel matrix derivative promotes healing of a surgical wound in the rat oral mucosa. J Periodontol 87: 601-609, 2016.

30. Laaksonen M, Suojanen J, Nurmenniemi S, Läärä E, Sorsa T and Salo T: The enamel matrix derivative (Emdogain) enhances human tongue carcinoma cells gelatinase production, migration and metastasis formation. Oral Oncol 44: 733-742, 2008.

31. Schwartz Z, Carnes DL Jr, Pulliam R, Lohmann $\mathrm{CH}$, Sylvia VL, Liu Y, Dean DD, Cochran DL and Boyan BD: Porcine fetal enamel matrix derivative stimulates proliferation but not differentiation of pre-osteoblastic $2 \mathrm{~T} 9$ cells, inhibits proliferation and stimulates differentiation of osteoblast-like MG63 cells, and increases proliferation and differentiation of normal human osteoblast NHOst cells. J Periodontol 71: 1287-1296, 2000.

32. Shimizu-Ishiura M, Tanaka S, Lee WS, Debari K and Sasaki T: Effects of enamel matrix derivative to titanium implantation in rat femurs. J Biomed Mater Res 60: 269-276, 2002.

33. Huang YC, Tanimoto K, Tanne Y, Kamiya T, Kunimatsu R, Michida M, Yoshioka M, Yoshimi Y, Kato Y and Tanne K: Effects of human full-length amelogenin on the proliferation of human mesenchymal stem cells derived from bone marrow. Cell Tissue Res 342: 205-212, 2010.

34. Hatakeyama J, Philp D, Hatakeyama Y, Haruyama N, Shum L, Aragon MA, Yuan Z, Gibson CW, Sreenath T, Kleinman HK and Kulkarni AB: Amelogenin-mediated regulation of osteoclastogenesis, and periodontal cell proliferation and migration. J Dent Res 85: 144-149, 2006

35. Kuramitsu-Fujimoto S, Ariyoshi W, Saito N, Okinaga T, Kamo M, Ishisaki A, Takata T, Yamaguchi K and Nishihara T: Novel biological activity of ameloblastin in enamel matrix derivative. J Appl Oral Sci 23: 49-55, 2015.

36. Hatakeyama J, Fukumoto S, Nakamura T, Haruyama N, Suzuki S, Hatakeyama Y, Shum L, Gibson CW, Yamada Y and Kulkarni AB: Synergistic roles of amelogenin and ameloblastin. J Dent Res 88: 318-322, 2009.

37. JonkeE, Gemperli AC,Zhang T,Özdemir B,Dard M,Rausch-Fan X and Andrukhov O: Effect of tyrosine-rich amelogenin peptide on behavior and differentiation of endothelial cells. Clin Oral Investig Feb 12, 2016 (Epub ahead of print).

38. Ravindranath RM, Tam WY, Nguyen $P$ and Fincham AG: The enamel protein amelogenin binds to the N-acetyl-D-glucosami ne-mimicking peptide motif of cytokeratins. J Biol Chem 275: 39654-39661, 2000. 